\title{
A critical assessment of chelant-enhanced metal phytoextraction
}

Bernd Nowack, Rainer Schulin and Brett H. Robinson

\author{
Institute of Terrestrial Ecosystems \\ ETH Zurich \\ Universitaetstrasse 16 \\ 8092 Zürich, Switzerland \\ Phone: +41 (0)44-633 6160 \\ Fax: +41 (0)44-633 1123 \\ e-mail: nowack@env.ethz.ch
}

Supporting Information
8 pages
3 Tables
1 Figure 


\section{Modeling extraction of $\mathrm{Pb}$ in the presence of chelants from soil}

We use $\mathrm{Pb}$ as an example because data on the extractability of this metal from soils in the presence and absence of chelating agents are available (1). The soil had been polluted in the field with $\mathrm{Pb}\left(723 \mathrm{mg} \mathrm{kg}^{-1}\right)$ by application of sewage sludge. The extraction of $\mathrm{Pb}$ was measured over the $\mathrm{pH}$ range from 3 to 9 in the absence of chelants and in the presence of EDTA and EDDS. Dissolved $\mathrm{Pb}$ as well as dissolved $\mathrm{Ca}$ and $\mathrm{Fe}$ were measured.

Soil-bound $\mathrm{Pb}$ can be modeled using two $\mathrm{pH}$-dependent binding sites. This concept of using a "soil-ligand" to model the solubility of metals in soils was introduced by Lindsay (2). Whereas Pb-binding in the absence of chelants can be modeled successfully using one "soilligand", this is not possible for the $\mathrm{Pb}$ solubilization in the presence of chelants. Two different binding sites with differing affinity and $\mathrm{pH}$ dependence were necessary to model the observed solubilization of $\mathrm{Pb}$. Fitting parameters are the protonation of the site, the $\log \mathrm{K}$ value of the "soil-ligand"-Pb complex and the total site concentration. The dependence on $\mathrm{pH}$ was fixed at the power of -1 and -2 for the two sites, representing different susceptibility of the site towards protonation. The total site concentration $\left(4.5 \mathrm{mmol} \mathrm{kg}{ }^{-1}\right)$ was chosen in slight excess of the total $\mathrm{Pb}$ content $\left(3.5 \mathrm{mmol} \mathrm{kg}^{-1}\right)$ and arbitrarily distributed between the two sites with a ratio of 1:2. Fitting parameters were therefore mainly the $\log \mathrm{K}$ values. The measured $\mathrm{Ca}$ concentration was also included in the model to account for competition between $\mathrm{Ca}$ and $\mathrm{Pb}$ for the chelant. The total chelant concentration was also corrected for the measured amount of solubilized $\mathrm{Fe}$, indicative of formation of $\mathrm{Fe}(\mathrm{III})$-complexes that decrease the amount of chelant available for complexing other metals. Table S1 presents the results of a manual fit of the observed data with these two sites. Figure $\mathrm{S} 1 \mathrm{a}$ shows the final model fit for $\mathrm{Pb}$ solubility in the absence and presence of EDDS.

\section{Modeling Ca extraction from a carbonate-free soil}

$\mathrm{Ca}$ extraction from a carbonate-free soil containing only exchangeable $\mathrm{Ca}$ was modeled using the same approach as for $\mathrm{Pb}$. Two binding sites $>\mathrm{X}_{3} \mathrm{Ca}$ and $>\mathrm{X}_{4} \mathrm{Ca}$ were used. The $\mathrm{pH}-$ dependent reactions are given in Table S1. Fig. S1b shows the experimental data for the solubilization of $\mathrm{Ca}$ as a function of $\mathrm{pH}$ together with the model fit. 
Table $\mathrm{S} 1$. Model for $\mathrm{Pb}$ and $\mathrm{Ca}$ adsorption onto soil based on experimental results from Tandy et al. (1)

\begin{tabular}{|l|l|l|}
\hline Species & Equation & $\begin{array}{l}\text { Site concentration } \\
\left(\mathrm{mmol} \mathrm{kg}^{-1}\right)\end{array}$ \\
\hline$>\mathrm{X}_{1} \mathrm{~Pb}$ & {$[\mathrm{~Pb}]\left[\mathrm{X}_{1}\right][\mathrm{H}]^{-1} 10^{2.61}$} & 1.5 \\
\hline$>\mathrm{X}_{2} \mathrm{~Pb}$ & {$[\mathrm{~Pb}]\left[\mathrm{X}_{2}\right][\mathrm{H}]^{-2} 10^{-1.32}$} & 3.0 \\
\hline$>\mathrm{X}_{3} \mathrm{Ca}$ & {$[\mathrm{Ca}]\left[\mathrm{X}_{3}\right][\mathrm{H}]^{-1} 10^{-4.32}$} & 250 \\
\hline$>\mathrm{X}_{4} \mathrm{Ca}$ & {$[\mathrm{Ca}]\left[\mathrm{X}_{4}\right][\mathrm{H}]^{-0.5} 10^{0.44}$} & 250 \\
\hline
\end{tabular}

Table S2: Conditions of the four model calculations used to model the influence of $\mathrm{Ca}$ and $\mathrm{Fe}$ on $\mathrm{Pb}$ extraction from soil.

$\begin{array}{ll}\mathrm{Pb} & 500 \mathrm{mg} \mathrm{kg}^{-1}\left(2.4 \mathrm{mmoles} \mathrm{kg}^{-1}\right) \\ \text { extraction } & \text { in suspension with } 20 \mathrm{~g} \mathrm{l}^{-1} \text { soil } \\ \text { EDTA/ EDDS } & 50 \mu \mathrm{M} \\ \text { EDTA:Pb } & 1 \\ \text { logK values } & \text { source of all logK values for EDTA, EDDS, Pb and Ca: reference (3) } \\ & \\ \text { case } 1 & \text { no Ca in the system } \\ \text { case 2 } & \text { exchangeable Ca }\left(200 \mathrm{mmoles} \mathrm{kg}^{-1}\right) \\ \text { case } 3 & \text { soil with } 10 \% \mathrm{CaCO}, \mathrm{CO}_{2}(\mathrm{~g}): 3.16 .10^{-4} \text { atm in extraction solution } \\ \text { case } 4 & \text { case 2) and additionally the Fe-phase hydrous ferric oxide (HFO) } \\ \end{array}$


Table S3: Soil and plant parameters for the calculations used to predict plant uptake

\begin{tabular}{|c|c|}
\hline soil $\mathrm{Pb}$ concentration & $1000 \mathrm{mg} \mathrm{kg}^{-1}$ \\
\hline depth of polluted soil & $0.2 \mathrm{~m}$ \\
\hline soil bulk density & $1.2 \mathrm{~g} \mathrm{~cm}^{-3}$ \\
\hline total $\mathrm{Pb}$ mass & $2400 \mathrm{~kg} \mathrm{ha}^{-1}$ \\
\hline soil water content & $0.3 \mathrm{~cm}^{3} \mathrm{~cm}^{-3}$ \\
\hline soil solution concentration if all $\mathrm{Pb}$ is mobilized & $16 \mathrm{mM}\left(3300 \mathrm{mg} \mathrm{L}^{-1}\right)$ \\
\hline evapotranspiration & $5 \mathrm{~mm} \mathrm{~d}^{-1}\left(5 \mathrm{~L} \mathrm{~m}^{-2} \mathrm{~d}^{-1}\right)$ \\
\hline yield (dry matter) & $30 \mathrm{t} \mathrm{ha}^{-1}$ \\
\hline
\end{tabular}



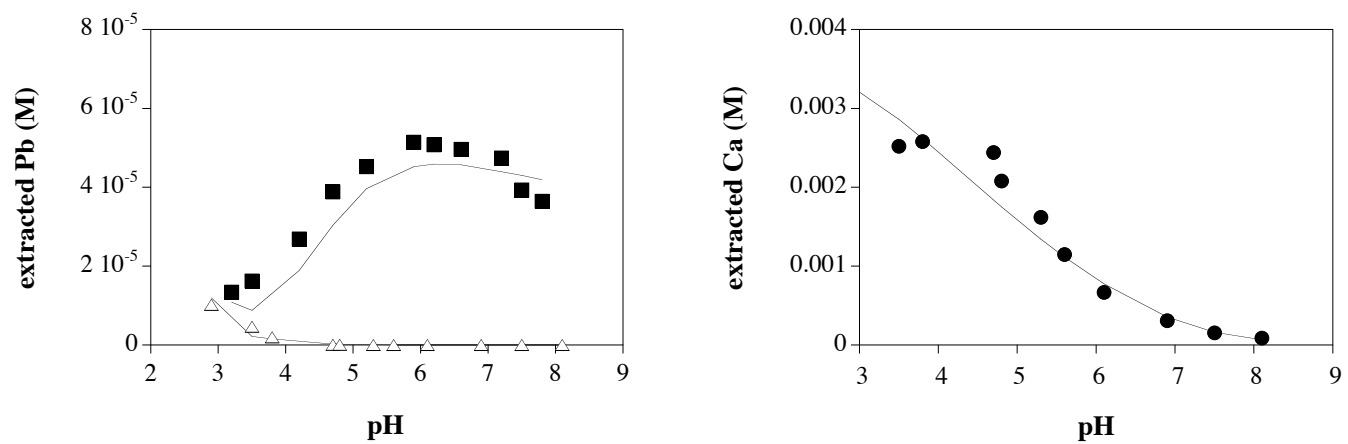

Fig. 1S: a) Measured and simulated $\mathrm{Pb}$ extraction in the absence (triangles) and presence of EDDS (squares) and b) Ca extraction from a non-calcareous soil (from Tandy et al. (1)). The simulations were obtained by fitting the equations shown in Table S1 to the experimental data.

\section{Cited References}

(1) Tandy, S.; Bossart, K.; Mueller, R.; Ritschel, J.; Hauser, L.; Schulin, R.; Nowack, B. Extraction of heavy metals from soils using biodegradable chelating agents. Environ. Sci. Technol. 2004, 38, 937-944.

(2) Lindsay, W. L. Chemical equilibria in soils; John Wiley \& Sons, New York, 1979.

(3) Martell, A. E.; Smith, R. M.; Motekaitis, R. J. "NIST critically selected stability constants of metal complexes, Version 6.0," NIST, 2001. 


\section{References used to draw figure 1 of the manuscript.}

Allen, H. E.; Chen, P. H. Remediation of metal contaminated soil by EDTA incorporating electrochemical recovery of metal and EDTA. Environ. Prog. 1993, 12, 284-293.

Barona, A.; Aranguiz, I.; Elias, A. Metal associations in soils before and after EDTA extractive decontamination: implications for the effectiveness of further clean-up strategies. Environ. Pollut. 2001, 113, 79-85.

De Gregori, I.; Fuentes, E.; Olivares, D.; Pinochet, H. Extractable copper, arsenic and antimony by EDTA solution from agricultural Chilean soils and its transfer to alfalfa plants (medicago sativa L.). J. Environ. Monit. 2004, 6, 38-47.

Elliott, H. A.; Brown, G. A. Comparative evaluation of NTA and EDTA for extractive decontamination of Pb-polluted soils. Water Air Soil Pollut. 1989, 45, 361-369.

Elliott, H. A.; Linn, J. H.; Shields, G. A. Role of Fe in extractive decontamination of Pbpolluted soils. Hazard. Waste Hazard. Mater. 1989, 6, 223-229.

Finzgar, N.; Kos, B.; Lestan, D. Washing of Pb contaminated soil using (S,S) ethylenediamine disuccinate and horizontal permeable barriers. Chemosphere 2004, 57, 655661.

Ghestem, J. P.; Bermond, A. EDTA extractability of trace metals in polluted soils: a chemical-physical study. Environ. Technol. 1998, 19, 409-416.

Hong, P. K. A.; Li, C.; Banerji, S. K.; Regmi, T. Extraction, recovery, and biostability of EDTA for remediation of heavy metal-contaminated soil. J. Soil Contam. 1999, 8, 81-103.

Hong, P. K. A.; Li, C.; Banerji, S. K.; Wang, Y. Feasibility of metal recovery from soil using DTPA and its biostability. J. Hazard. Materials 2002, B94, 253-272.

Kim, C.; Lee, Y.; Ong, S. K. Factors affecting EDTA extraction of lead from leadcontaminated soils. Chemosphere 2003, 51, 845-853.

Kos, B.; Lestan, D. Soil washing of $\mathrm{Pb}, \mathrm{Zn}$ and $\mathrm{Cd}$ using biodegradable chelator and permeable barriers and induced phytoextraction of Cannabis sativa. Plant Soil 2004, 263, 4351.

Lee, C. C.; Marshall, W. D. Recycling of complexometric extractants to remediate soil contaminated with heavy metals. J. Environ. Monit. 2002, 4, 325-329. 
Lestan, D.; Hanc, A.; Finzgar, N. Influence of ozonation on extractability of $\mathrm{Pb}$ and $\mathrm{Zn}$ from contaminated soils. Chemosphere 2005, 61, 1012-1019.

Linn, J. H.; Elliott, H. A. Mobilization of $\mathrm{Cu}$ and $\mathrm{Zn}$ in contaminated soil by nitrilotriacetic acid. Water Air Soil Pollut. 1988, 37, 449-458.

Manouchehri, N.; Besancon, S.; Bermond, A. Major and trace metal extraction from soil by EDTA: equilibrium and kinetic studies. Anal. Chim. Acta 2006, 559, 105-112.

Meers, E.; Lesage, E.; Lamsal, S.; Hopgood, M.; Vervaeke, P.; Tack, F. M. G.; Verloo, M. G. Enhanced phytoextraction: I. Effect of EDTA and citric acid on heavy metal mobility in a calcareous soil. Int. J. Phytorem. 2005, 7, 129-142.

Neubauer, U.; Furrer, G.; Kayser, A.; Schulin, R. Siderophores, NTA, and citrate: potential soil amendments to enhance heavy metal mobility in phytoremediation. Int. J. Phytorem. 2000, 2, 353-368.

Papassiopi, N.; Tambouris, S.; Kontopoulos, A. Removal of heavy metals from calcareous contaminated soils by EDTA leaching. Water Air Soil Pollut. 1999, 109, 1-15.

Stanhope, K. G.; Young, S. D.; Hutchinson, J. J.; Kamath, R. Use of isotopic dilution techniques to assess the mobilization of nonlabile $\mathrm{Cd}$ by chelating agents in phytoremediation. Environ. Sci. Technol. 2000, 34, 4123-4127.

Sun, B.; Zhao, F. J.; Lombi, E.; McGrath, S. P. Leaching of heavy metals from contaminated soils using EDTA. Environ. Pollut. 2001, 113, 111-120.

Tandy, S.; Bossart, K.; Mueller, R.; Ritschel, J.; Hauser, L.; Schulin, R.; Nowack, B. Extraction of heavy metals from soils using biodegradable chelating agents. Environ. Sci. Technol. 2004, 38, 937-944.

Theodoratus, P.; Papassiopi, N.; Georgoudis, T.; Kontopoulos, A. Selective removal of lead from calcareous polluted soils using the Ca-EDTA salt. Water Air Soil Pollut. 2000, 122 , 351-368.

Van Benschoten, J. E.; Reed, B. E.; Matsumoto, M. R.; McGarvey, P. J. Metal removal by soil washing for an iron oxide coated sandy soil. Water Environ. Res. 1994, 66, 168-174. Vandevivere, P.; Hammes, F.; Verstraete, W.; Feijtel, T.; Schowanek, D. Metal decontamination of soil, sediment, and sewage sludge by means of transition metal chelant (S,S)-EDDS. J. Environ. Eng. 2001, 127, 802-811. 
Wasay, S. A.; Parker, W. J.; Van Geel, P. J. Contamination of a calcareous soil by battery industry wastes. II. Treatment. Can. Civ. Eng. 2001, 28, 349-354.

Xie, T.; Marshall, W. D. Approaches to soil remediation by complexometric extraction of metal contaminants with regeneration of reagents. J. Environ. Monit. 2001, 3, 411-416.

Yu, J.; Klarup, D. Extraction kinetics of copper, zinc, iron and manganese from contaminated sediment using disodium ethylenediaminetetraacetate. Water Air Soil Pollut. 1994, 75, 205225.

Yukselen, M. A.; Gokyay, O. Leachability of metals from soil contaminated by mining activities. Environ. Eng. Sci. 2006, 23, 125-132. 